\title{
Two New Species of Impatiens from China, and Taxonomic Insights into the Longifilamenta Group, Which Is Endemic to China
}

\author{
Yong-Xiu Song ${ }^{1,2}$, Yan Xiao ${ }^{1,3}$, Shuai Peng ${ }^{2,4,5}$, Yi-Yan Cong ${ }^{1, *}$ and Guang-Wan Hu $2,4, *$ (D) \\ 1 College of Life Sciences, Hunan Normal University, Changsha 410081, China; \\ SongYongXiu130@163.com (Y.-X.S.); yanxiao_begonia@163.com (Y.X.) \\ 2 CAS Key Laboratory of Plant Germplasm Enhancement and Specialty Agriculture, Wuhan Botanical Garden, \\ Chinese Academy of Sciences, Wuhan 430074, China; pengshuai183@163.com \\ 3 Shanghai Chenshan Plant Science Research Center, Chinese Academy of Sciences, Shanghai 430074, China \\ 4 Sino-Africa Joint Research Center, Chinese Academy of Sciences, Wuhan 430074, China \\ 5 Wuhan Botanical Garden, Chinese Academy of Sciences, University of Chinese Academy of Sciences, \\ Beijing 100049, China \\ * Correspondence: congyiyan2004@aliyun.com (Y.-Y.C.); guangwanhu@wbgcas.cn (G.-W.H.)
}

Citation: Song, Y.-X.; Xiao, Y.; Peng, S.; Cong, Y.-Y.; Hu, G.-W. Two New Species of Impatiens from China, and Taxonomic Insights into the Longifilamenta Group, Which Is Endemic to China. Plants 2021, 10, 1697. https://doi.org/10.3390/ plants10081697

Academic Editor: Marco C. Simeone

Received: 2 August 2021

Accepted: 13 August 2021

Published: 18 August 2021

Publisher's Note: MDPI stays neutral with regard to jurisdictional claims in published maps and institutional affiliations.

Copyright: (C) 2021 by the authors. Licensee MDPI, Basel, Switzerland. This article is an open access article distributed under the terms and conditions of the Creative Commons Attribution (CC BY) license (https:// creativecommons.org/licenses/by/ $4.0 /)$.

\begin{abstract}
Impatiens longshanensis (The LSID for the name Impatiens longshanensis is: 77219154-1) sp. nov. and I. lihengiana (The LSID for the name I. lihengiana is: 77219153-1) sp. nov., from Hunan, China, are described and illustrated here. The molecular phylogenetic study suggests that I. longshanensis and I. lihengiana should be placed in the I. sect. Impatiens. A detailed description, diagnostic characters between the two new species and allied species, pollen and seed morphology, and color photographs are provided. In addition, based on wide sampling, we found that the longifilamenta group, an endemic group to China, whose members have basal lobes of lateral united petals with long filamentous hairs, shows significant morphological variability. In this paper, we discuss the taxonomic significance of morphological characteristics within this group. Based on a literature review and observation of living materials in the field, an updated identification key for this group is also proposed.
\end{abstract}

Keywords: Balsaminaceae; China; Impatiens lihengiana; Impatiens longshanensis; morphology; phylogeny; taxonomy

\section{Introduction}

Balsaminaceae comprises two genera, the monotypic Hydrocera Blume ex Wight \& Arnott [1] and Impatiens Linnaeus [2]. Impatiens is one of the most species-rich genera of angiosperms, having more than 1000 species. These are mainly distributed in the mountainous regions of the tropics and subtropics, and have tropical Africa, Madagascar, South India and Sri Lanka, Sino-Himalaya, and South-East Asia as their centers of diversity [3,4]. The genus is distinguished by zygomorphic flowers with tremendous diversity in corolla color and morphology, and lateral petals always united in pairs. The fruit is a fleshy, explosive capsule, and seeds are often dispersed elastically from valves when ripe [5,6]. Impatiens species occur in diverse habitats, such as in forest understories, roadside ditches, valleys, abandoned fields, along streams and in seepages, usually in mesic or wet conditions, although some species can tolerate drier habitats [6]. Due to their beautiful appearance and long flowering period, many species of Impatiens are grown all over the world as ornamental plants [7]. Many new species of Impatiens have been discovered and described in recent years [8-15]. There are more than 280 species of Impatiens distributed in China [5,16,17]. Most of these are found in southwestern China, which is a key diversity area of the genus.

As is well known, Impatiens is notoriously difficult to classify [3,18]. Morphologically, Impatiens are usually fleshy plants, with fine and fragile flowers, usually folded and co- 
alesced in dried specimens, hence losing their original shape and therefore difficult to reconstruct. The botanist Hooker called them "a terror to botanists" and "deceitful above all plants, and desperately wicked". Yu et al. [6] divided the genus Impatiens into two subgenera, I. subgen. Clavicarpa and subgen. Impatiens [15], based on both morphological and molecular evidence, and the latter was further subdivided into seven sections: Semeiocardium, Racemosae, Fasciculatae, Impatiens, Tuberosae, Scorpioidae, and Uniflorae.

The longifilamenta group in Impatiens was once treated as I. sect. longifilamenta [17], then merged into I. sect. Impatiens [6]. This group is endemic to China, and markedly characterized by its 1- or 2-flowered racemose inflorescences, pedicel with 2 bracts, lower sepal saccate or funnelform, with striate, basal lobes of lateral united petals with a filamentous long hair. However, this group has not attracted much attention, and there are few studies related to it. In this paper, we discuss the morphological characteristics with taxonomic significance in this group, and provide its updated identification key.

During the botanical explorations from 2012 to 2020 in Longshan County, Hunan province, the authors encountered two interesting species of Impatiens growing on wet shady habitats under an evergreen forest. Specimens were collected carefully, and the flowers and fruits were preserved in formalin-acetic-alcohol (FAA) solution for further identification. After careful examination of the relevant specimens and literature $[5,16,17]$, the authors confirm the two as new species, and describe them here.

\section{Results}

\subsection{Taxonomic Treatment of the New Species}

\subsubsection{Taxonomic Description of Impatiens longshanensis}

Impatiens longshanensis Y. Y. Cong \& Y. X. Song, sp. nov. Figures 1 and 2 and Figure S1.

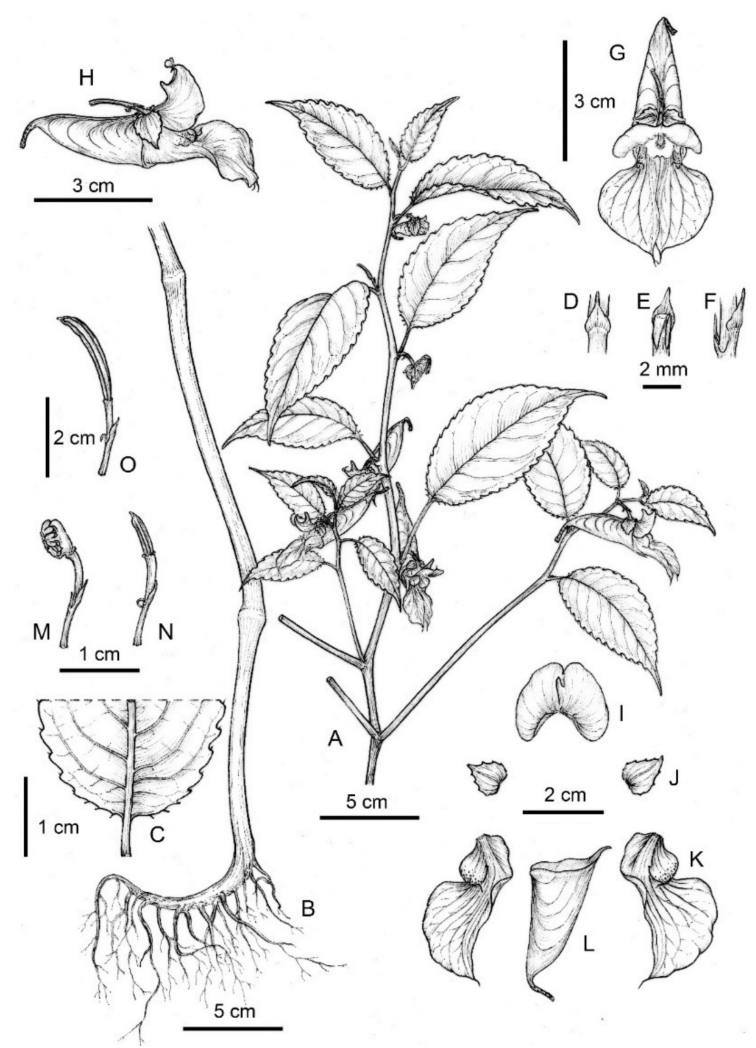

Figure 1. Impatiens longshanensis. (A) Plant; (B) root; (C) basal portion of abaxial leaf surface; (D) bracts in dorsal view; (E) bracts in front view; (F) bracts in lateral view; (G) flower in anterior view; (H) flower in lateral view; (I) dorsal petal; (J) lateral sepal; (K) lateral united petal; (L) lower sepal; (M) anthers; (N) ovary; (O) capsule. 

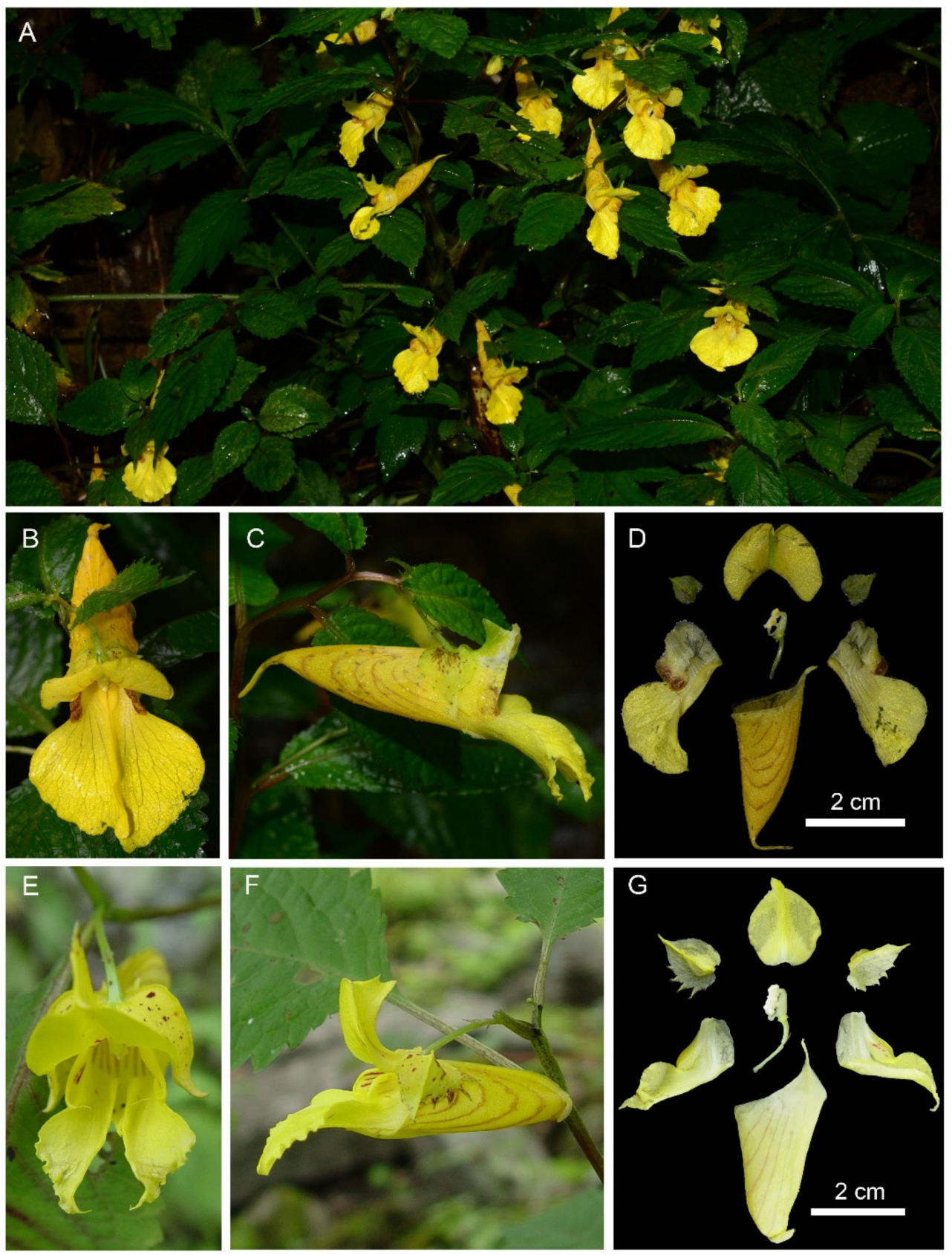

Figure 2. Impatiens longshanensis. (A) Habit; (B) anterior view of flower; (C) lateral view of flower; (D) flower structure. (E-G) Impatiens dicentra. (E) Anterior view of flower; (F) lateral view of flower; (G) flower structure.

Type: China, Hunan, Longshan County, Bamian Mountain, Zisheng Bridge, under moist and shady places, $109^{\circ} 15^{\prime} 05.92^{\prime \prime}$ E, $28^{\circ} 52^{\prime} 30.24^{\prime \prime}$ N, altitude $1194 \mathrm{~m}, 7$ October 2020, Yi-Yan Cong 35,443 (holotype: HIB, isotype: HNNU).

\section{Diagnosis}

Impatiens longshanensis is morphologically similar to I. dicentra Franch. ex Hook. f., but differs due to its suborbicular lamina base (vs. lamina base cuneate); green, equilateral lateral sepals, 5.5-7 mm wide, coarsely dentate on both sides, and inconspicuously thickened abaxial midvein (vs. yellow, inequilateral, 12-14 mm wide, coarsely dentate on one side, rarely entire, abaxial midvein narrowly carinate); lower sepal $1.85-2.3 \mathrm{~cm}$ deep 
(vs. 3-5 cm deep); reniform dorsal petal (vs. orbicular); oblong basal lobe (vs. lanceolate); and dolabriform distal lobes (vs. lanceolate).

Additional Material Examined

China, Hunan, Longshan County, Bamian Mountain, 109 26 $37^{\prime \prime}$ E, $28^{\circ} 96^{\prime} 58^{\prime \prime} \mathrm{N}$, altitude 1336 m, 27 July 2013, Yan Xiao LS-2238 (CSH).

\section{Description}

Annual herb, $45-80 \mathrm{~cm}$ tall. Stem erect, slender, slightly ridged base $0.5-0.7 \mathrm{~cm}$ in diam, well branched, nodes swollen in lower part. Leaves alternate, petiole $1-3 \mathrm{~cm}$. Lamina $4.5-8 \times 1.2-3.9 \mathrm{~cm}$, ovate or narrowly elliptic, membranaceous, glabrous on both surfaces, apex cuspidate, base suborbicular, with 3-4 pairs stipitate glands at basal margin, margin crenate-serrate, setose between marginal teeth, lateral veins 5- 8 pairs. Inflorescences in upper leaf axils, 1-flowered; peduncles short, $0.6-1.1 \mathrm{~cm}$ long. Pedicels 2-bracteate, lower bracts linear, upper bracts ovate, persistent. Flowers pale yellow, large, $3-4.5 \mathrm{~cm}$ long. Sepals: lateral sepals 2, broadly ovate-orbicular, equilateral, $6.5-9 \mathrm{~mm}$ long, 5.5-7 mm wide, green, acuminate at apex, coarsely dentate on both sides, abaxial midvein inconspicuously thickened; lower sepal red striate, saccate, $1.85-2.3 \mathrm{~cm}$ deep excluding spur, mouth 1.2-1.6 cm wide, anterior gradually narrowed downward into a long beak, base gradually narrowed into a spur, ca $1 \mathrm{~cm}$, incurved, 2-lobed. Petals: dorsal petal reniform, 11-13.5 mm long, 16-22 mm wide, base suborbicular, apex emarginate, shortly rostellate, abaxial midvein cristate, green, lateral united petals not clawed, $1.55-2.1 \mathrm{~cm}$ long, 2-lobed, basal lobe 8-12 × 6-8.5 mm, oblong, apex with a filamentous long hair, distal lobes 18-25 × 8.5-13 mm, dolabriform, margin entire, apex obtuse, abruptly narrowed into a short filamentous hair, auricle inflexed. Stamens 5, 5-7.5 mm long, filaments linear, free for about $1 / 2$ of their length. Anthers ovoid, joined into a ring surrounding the ovary apex, apex obtuse, 2-2.5 mm long; ovary superior, 4-5.5 mm long, 5-carpellate, erect, fusiform, placentation axile. Capsule linear, $1.6-2.5 \mathrm{~cm}$ long, fleshy, 5 -valved. Seeds many, subellipsoid.

Etymology

The specific epithet "longshanensis" refers to the locality of the type specimen, Longshan County, Hunan, China.

Phenology: Flowering and fruiting were observed in the field from September to November.

\section{Micromorphological Observations}

Pollen grains: Impatiens longshanensis and I. dicentra are oblong in polar view, 4-colpate, exine with irregularly reticulate ornamentation, dense granules in lumina, the former average size of E1 $\times$ E2 $=26.12(23.83-27.71) \times 15.05(14.37-15.56) \mu \mathrm{m}$ (Figure 3A-C), the latter average size of E1 $\times$ E2 $=29.66(26.20-32.81) \times 18.04(16.73-20.01) \mu \mathrm{m}$ (Figure 3D-F). The surface of the pollen grains under SEM of the two species appears to be similar.

Seeds: seeds of I. longshanensis subellipsoid, $2.47 \times 2.22 \mathrm{~mm}$, ratio of L (length)/W ( width) $=1.11$, under SEM (Figure $3 \mathrm{M}-\mathrm{O}$ ), surface with irregularly reticulate ornamentation, sparse granules can be seen under high magnification (Figure 3O). Seeds of I. dicentra subellipsoid, $2.50 \times 2.20 \mathrm{~mm}$, ratio of L (length) $/ \mathrm{W}$ (width) $=1.14$, under SEM (Figure 3P-R), surface with irregularly reticulate ornamentation, dense granules can be seen under high magnification (Figure 3R). 


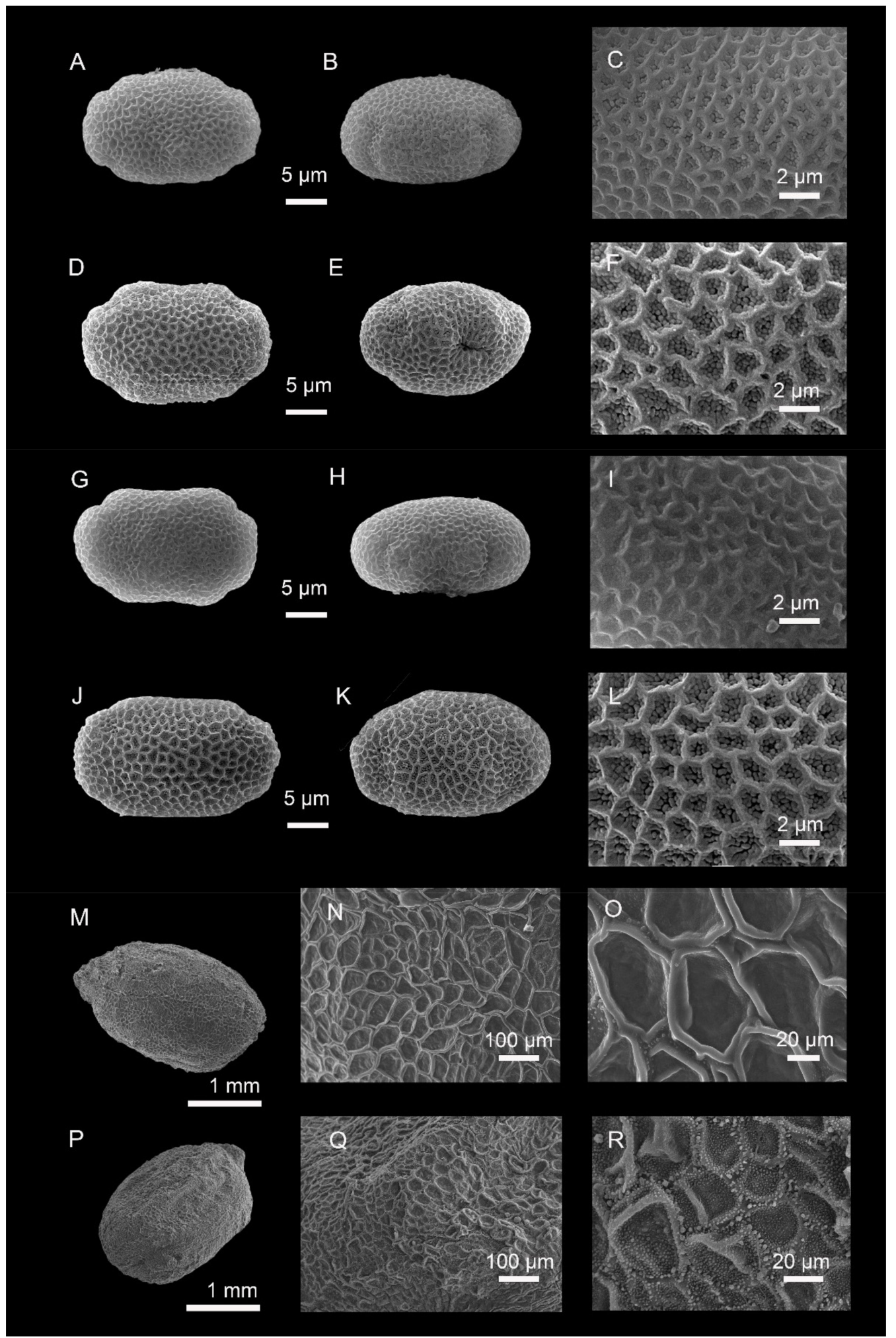

Figure 3. (A-C,M-O) Impatiens longshanensis; (D-F,P-R) I. dicentra; (G-I) I. lihengiana; (J-L) I. davidii; (A-L) scanning electron microscope images of pollen grains; $(\mathbf{A}, \mathbf{D}, \mathbf{G}, \mathbf{J})$ polar view; $(\mathbf{B}, \mathbf{E}, \mathbf{H}, \mathbf{K})$ equatorial view; (C,F,I,L) partial view; (M-R) scanning electron microscope images of seeds; $(\mathbf{M}, \mathbf{P})$ whole view; $(\mathbf{N}, \mathbf{O}, \mathbf{Q}, \mathbf{R})$ partial view. 


\section{Habitat and Distribution}

Impatiens longshanensis is currently known only from the type locality in Longshan County, Hunan Province, China (Figure 4). It was found growing in shaded moist places, along creek sides, at altitudes of between 1000 and $1300 \mathrm{~m}$.

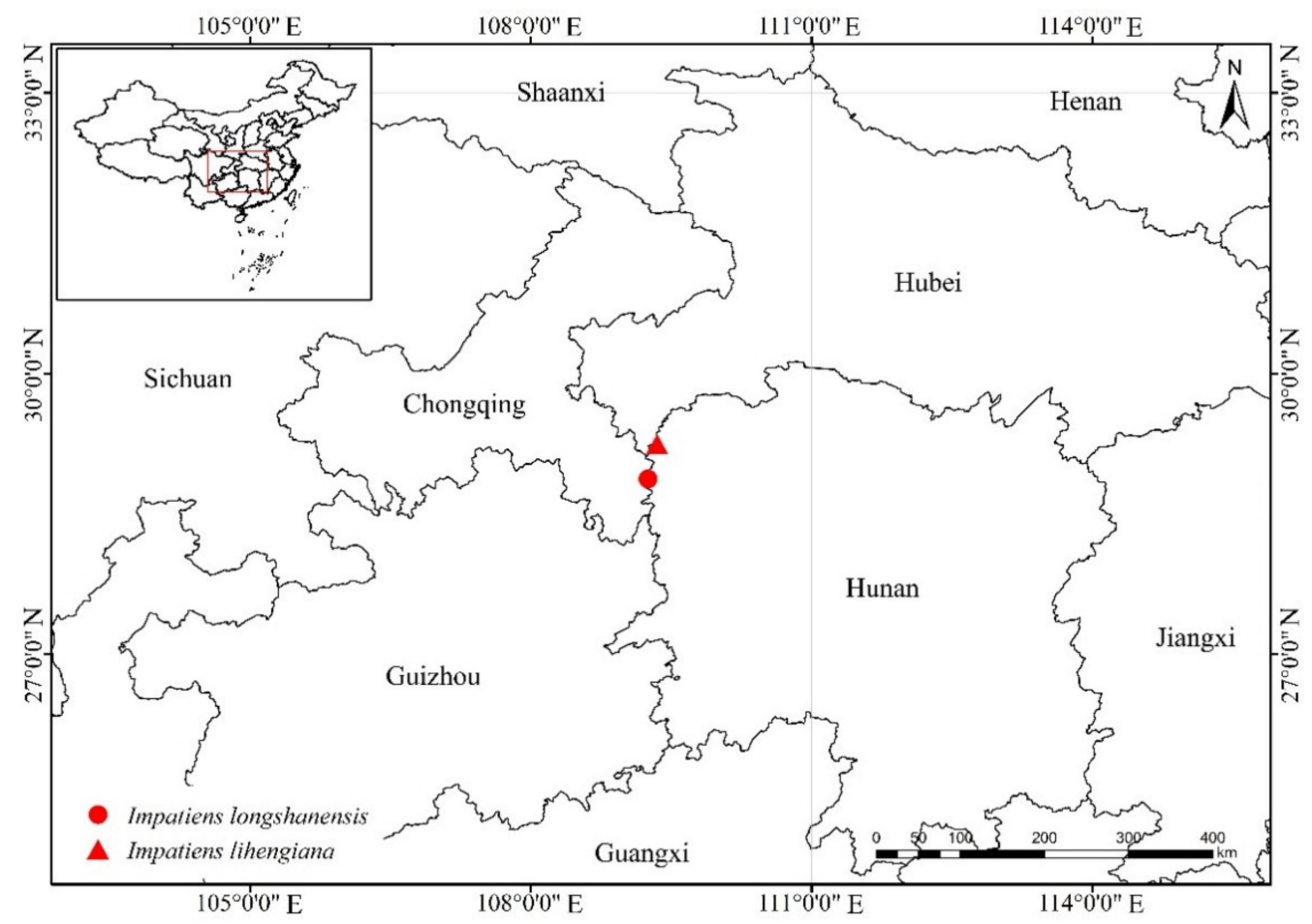

Figure 4. Geographic distribution of Impatiens longshanensis and Impatiens lihengiana in China.

\subsubsection{Taxonomic Description of Impatiens lihengiana}

Impatiens lihengiana Y. Y. Cong \& G. W. Hu, sp. nov. Figures 5 and 6 and Figure S2.

Type: China, Hunan, Longshan County, Huoyanguitang Cave, under moist and shady places, $109^{\circ} 20^{\prime} 59^{\prime \prime}$ E, $29^{\circ} 14^{\prime} 41^{\prime \prime} \mathrm{N}$, altitude $517 \mathrm{~m}$, 4 November 2012, Yan Xiao LS-794 (holotype: $\mathrm{CSH}$, isotype: $\mathrm{CSH}$ ).

\section{Diagnosis}

The new species is morphologically similar to Impatiens davidii Franch, but differing in having narrowly elliptic or narrowly ovate-elliptic leaf blades (vs. ovate-oblong or ovatelanceolate); petiole 1.5-2.5 cm (vs. 4-8 cm); lateral sepals yellow-green, purple spotted, 1-veined (vs. yellow, unspotted, 9-veined); lower sepal funnelform (vs. saccate); dorsal petal apex long rostellate (vs. short rostellate); lateral united petals not clawed, $2.5-2.8 \mathrm{~cm}$ long (vs. clawed, 1.5-2 cm long); and basal lobe ovate-lanceolate (vs. oblong).

\section{Description}

Annual herb, 60-75 cm tall. Stem erect, slender, base $0.5-0.7 \mathrm{~cm}$ in diam, rarely branched. Leaves alternate, petiole $1.5-2.5 \mathrm{~cm}$. Lamina 6-12.5 $\times 3-4.2 \mathrm{~cm}$, narrowly elliptic or narrowly ovate-elliptic, membranaceous, glabrous on both surfaces, apex cuspidate, base cuneate, margin crenate-serrate, setose between marginal teeth, lateral veins 6-8 pairs. Inflorescences in upper leaf axils, 1-flowered; peduncles $0.6-1.1 \mathrm{~cm}$ long. Pedicels 2bracteate, lower bracts linear, upper bracts ovate ca. $0.5 \mathrm{~cm}$ long, ca. $0.3 \mathrm{~cm}$ wide, apex long acuminate. Flowers yellow, large, 4-4.5 cm long. Sepals: lateral sepals 2, yellowgreen, purple spotted, suborbicular, $8-10 \mathrm{~mm}$ long, ca. $8 \mathrm{~mm}$ wide, 1-veined, acuminate at apex, lower sepal red striate, funnelform, 2-2.2 cm deep excluding spur, mouth 18-22 mm wide, base gradually narrowed into a spur, 10-12 mm long, incurved, 2-lobed. Petals: 
dorsal petal suborbicular, 15-17 mm long, 12-14 mm wide, apex long rostellate, abaxial midvein cristate, green, lateral united petals not clawed, $2.5-2.8 \mathrm{~cm}$ long, 2-lobed, basal lobe 10-12.5 × 2-3.5 mm, ovate-lanceolate, apex with a filamentous long hair, ca. $1 \mathrm{~mm}$ long, distal lobes 19-22 × 10-12 mm, dolabriform, apex obtuse, constricted into a filamentous hair, auricle inflexed. Stamens 5, ca. $5 \mathrm{~mm}$ long, filaments linear, free for about $1 / 2$ of their length. Anthers ovoid, joined into a ring surrounding the ovary apex, apex obtuse, ca. $4.5 \mathrm{~mm}$ long; ovary fusiform, superior, ca. $5 \mathrm{~mm}, 5$-carpellate, erect, placentation axile. Capsule linear, 3.3-3.5 cm long, fleshy, 5-valved.

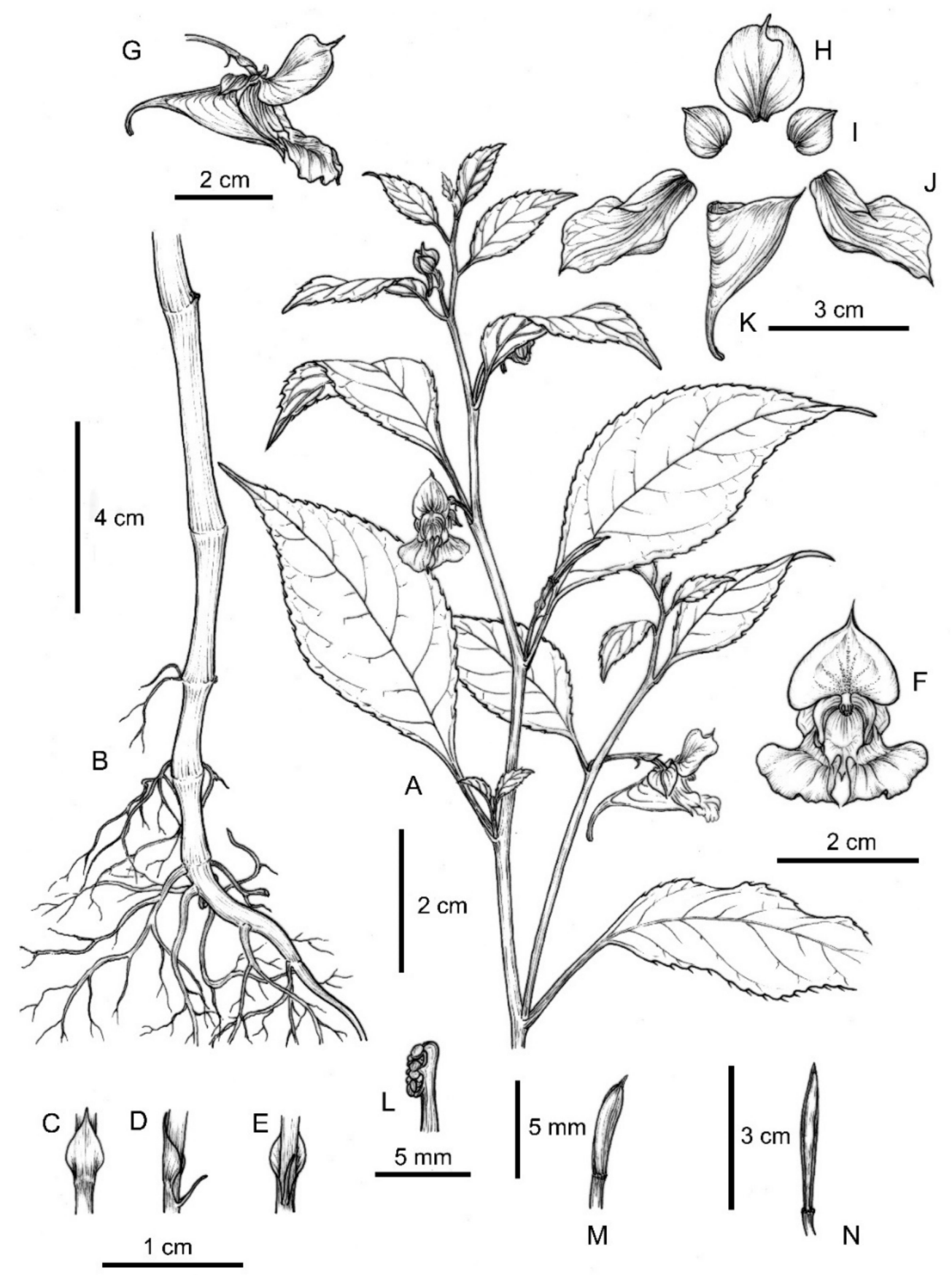

Figure 5. Impatiens lihengiana (A) Plant; (B) root; (C) bracts in dorsal view; (D) bracts in lateral view; (E) bracts in anterior view; (F) flower in anterior view; (G) flower in lateral view; (H) dorsal petal; (I) lateral sepal; (J) lateral united petal; (K) lower sepal; (L) anthers; (M) ovary; (N) capsule. 

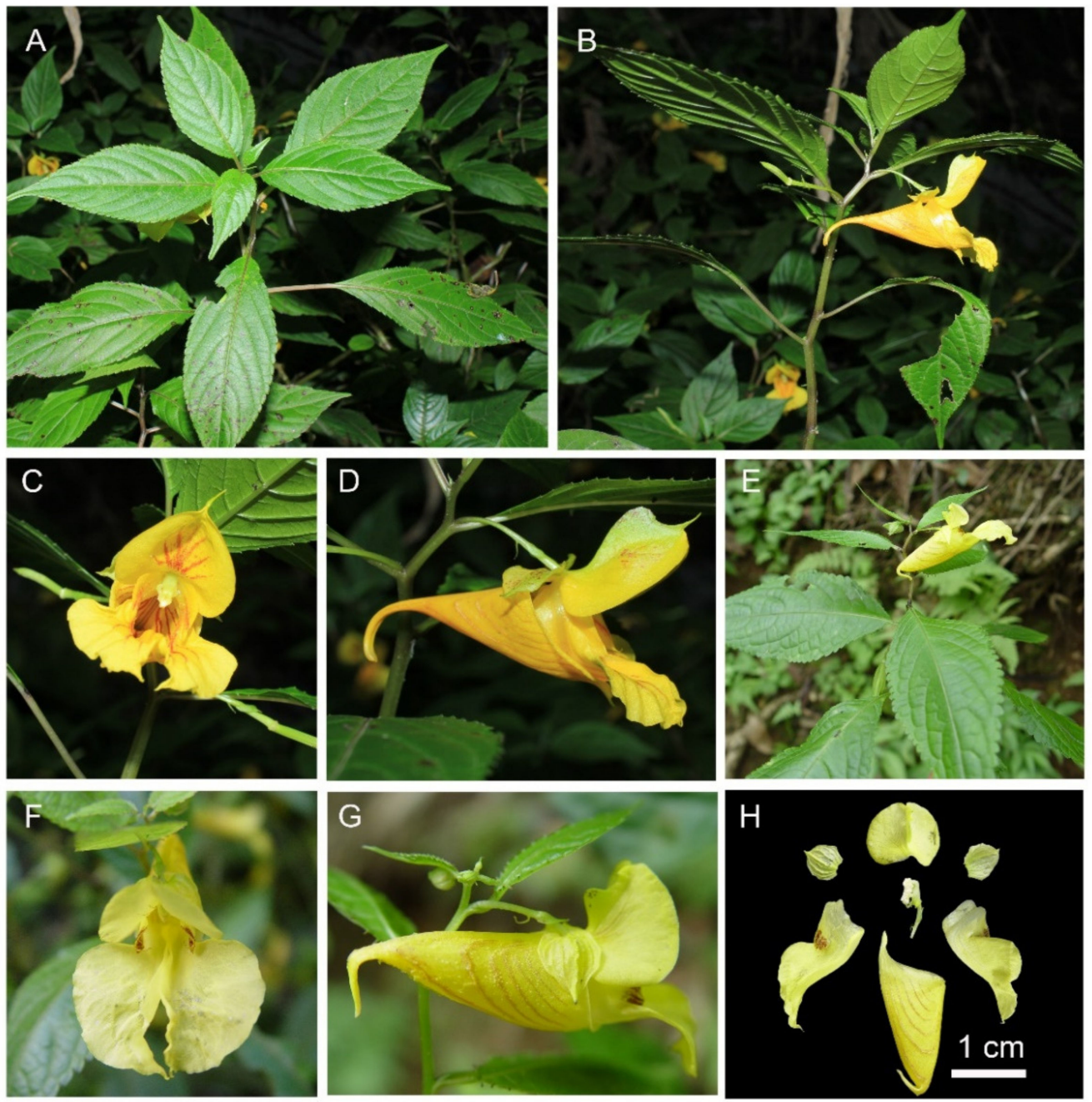

Figure 6. Impatiens lihengiana. (A) Plant; (B) flower branches; (C) anterior view of flower; (D) lateral view of flower. (E-H) Impatiens davidii. (E) Flower branches; (F) anterior view of flower; (G) lateral view of flower; $(\mathbf{H})$ flower structure.

Etymology

The specific epithet "lihengiana" is given in honor of Prof. Heng Li, a taxonomist at Kunming Institute of Botany, Chinese Academy of Sciences, who has made significant contributions to plant taxonomy.

Phenology: Flowering and fruiting were observed in the field from September to November.

Habitat and Distribution

Impatiens lihengiana is currently known only from the type locality in Longshan County, Hunan Province, China (Figure 4). It grows in shaded moist places, along streams, between 450 and $650 \mathrm{~m}$.

\section{Micromorphological Observations}

Pollen grains: Impatiens lihengiana and I. davidii are oblong in polar view, 4-colpate, exine with irregularly reticulate ornamentation, dense granules in lumina, the former average size of E1 $\times$ E2 $=25.53(22.28-28.58) \times 15.28(13.15-16.92) \mu \mathrm{m}$ (Figure 3G-I), the latter average size of E1 $\times$ E2 $=25.10(22.68-27.84) \times 16.76(15.12-18.01) \mu \mathrm{m}($ Figure 3J-L). The surface of the pollen grains under SEM of the two species appears to be similar. 


\subsection{Molecular Phylogenetic Analysis}

Consistent with Yu et al. [6], Impatiens can be divided into I. subgen. Clavicarpa and I. subgen. Impatiens. Within I. subgen. Impatiens, several sections can be recognized. The molecular phylogenetic analysis of Impatiens based on ITS and $a t p B-r b c L$ supported ten species, namely, I. soulieana, I. lecomtei, I. platychlaena, I. bullatisepala, I. davidii, I. dicentra, I. fissicornis, I. tayemonii, and our two proposed new species, to cluster into a clade which belongs to I. sect. Impatiens (Figure 7). This result is also consistent with the morphological classification in which these species are all characterized by lateral united petals with a long filamentous appendage.
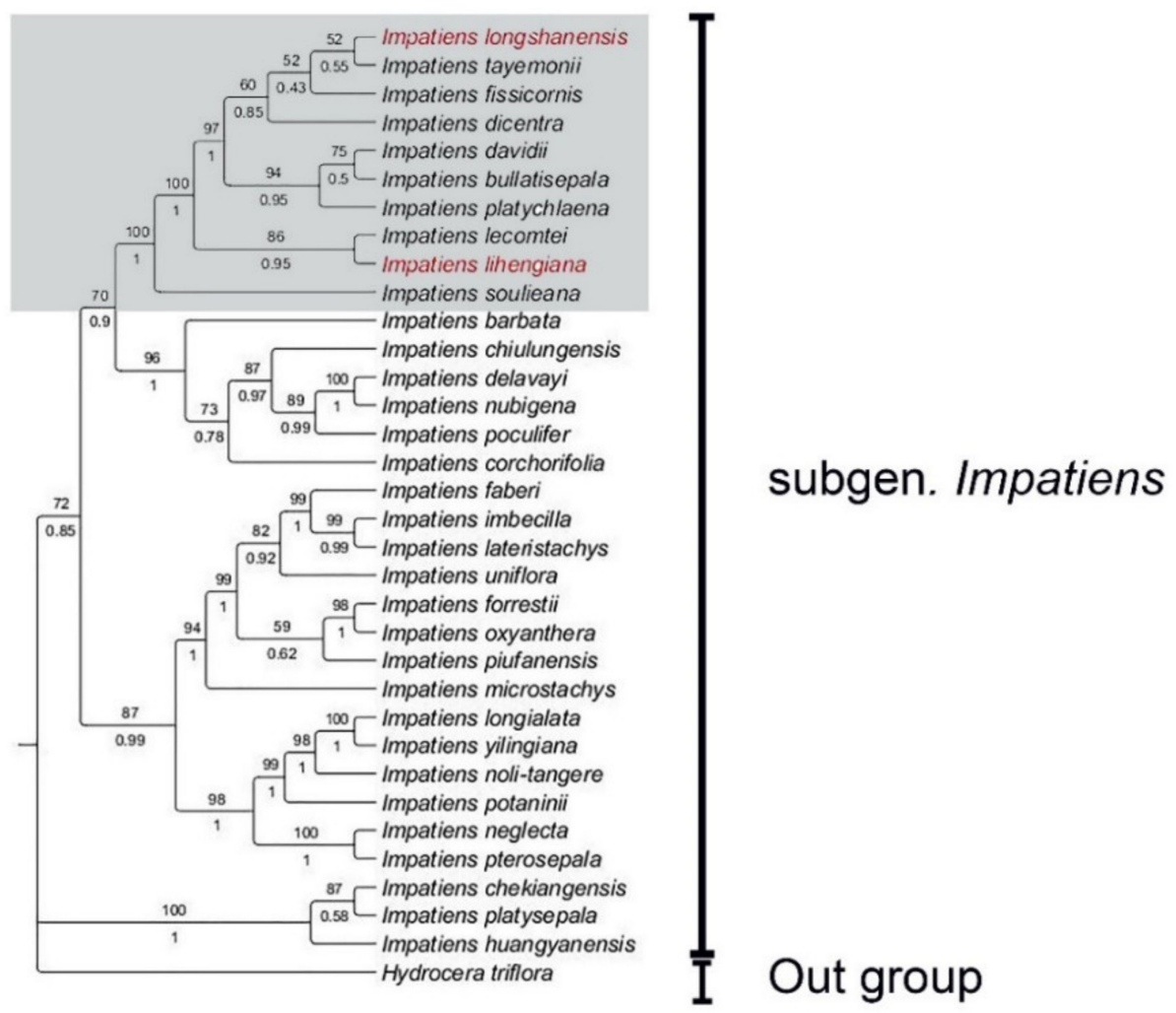

Figure 7. Phylogenetic tree inferred from Bayesian analysis and maximum likelihood analyses based on a combined dataset of nrDNA ITS and cpDNA $a t p B-r b c L$ sequences. Values above the branches are maximum parsimony bootstrap supports, and below the branches are Bayesian posterior probabilities. Two new species are highlighted in red, longifilamenta group is highlighted in gray background.

\subsection{Taxonomic Insights}

The results of our phylogenetic reconstruction show that the longifilamenta group in Impatiens is a phylogenetically and morphologically cohesive group (Figure 7). As is currently known, this group consists of 25 species growing as annual herbs, characterized by 1-3 flowered racemose inflorescence, and basal lobes of lateral united petals having an apex with a filamentous appendage $[5,13,14,19-22]$. The morphological characteristics of lateral sepals, lower sepals, and lateral united petals have a taxonomic significance within these species, crucial for their identification. They are endemic to China, distributed from Taiwan to Qinghai-Tibet Plateau.

The molecular data supported that Impatiens soulieana is a separate subclade (Figure 7). Morphologically, the apex of distal lobes in Impatiens soulieana is retuse (a distinctive characteristic that defines this species), whereas the apex of distal lobes in other species in this clade is entire, and the apex is constricted into filamentous hair. Thus, the phylogenetic hypothesis is congruent with the observed morphological distinctiveness. Interestingly, the 
apex of distal lobes in Impatiens oblongipetala is also retuse, but more phylogenetic evidence is needed to clearly understand its taxonomic status.

Based on morphological characteristics, there are significant variations in the structure of the flower within this group (Figure 8A-F). The distinctive characteristic of this group is that the apex of distal lobes of lateral united petals has a filamentous appendage, with few exceptions, and the filamentous appendages are also diverse (Figure 8G-O). Previous descriptions of this group were mostly based on dried herbarium specimens. However, the filamentous appendages of distal lobes also need to be observed with a stereomicroscope and recorded in the field, because their complex morphological characters are often poorly preserved in herbarium materials and, hence, the filamentous appendages may be ignored.

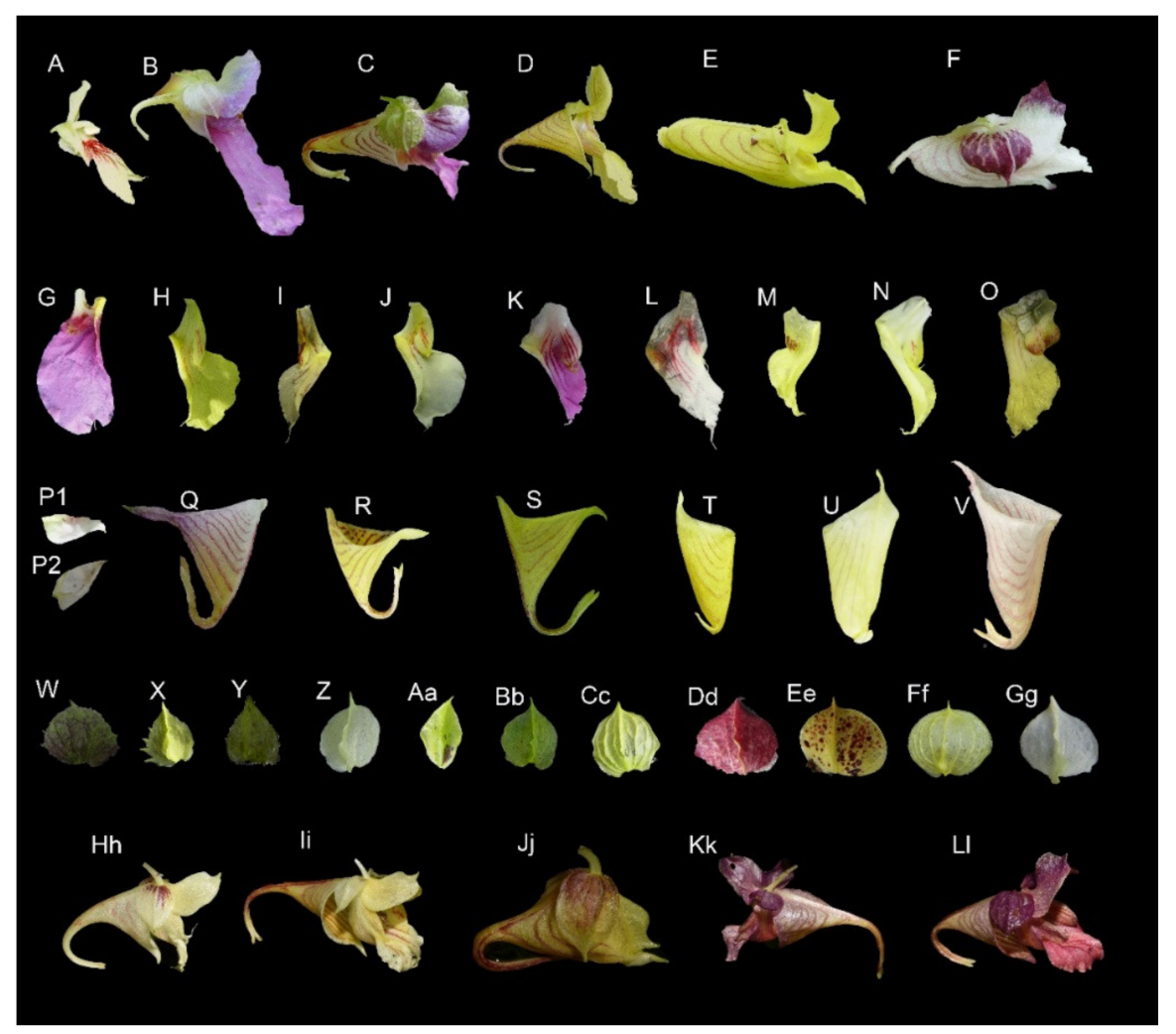

Figure 8. Floral structural diversity of longifilamenta group. (A-F,Hh-Ll) Flower in lateral view; (G-O) lateral united petals; (P1,P2-V) lower sepal; (W-Z,Aa-Gg) lateral sepals; $(\mathbf{A}, \mathbf{P 1}, \mathbf{P 2})$ I. shennongensis; (B,G) I. oblongipetala; $(\mathbf{C}, \mathbf{K}, \mathbf{Q}, \mathbf{W})$ I. weihsiensis; $(\mathbf{D}, \mathbf{H}, \mathbf{S}, \mathbf{B b})$ I. soulieana; $(\mathbf{E}, \mathbf{N}, \mathbf{U}, \mathbf{X})$ I. dicentra; (F,L,V,Dd-Gg) I. platychlaena; (I,Z) I. conaensis; (J,R,Aa,Hh-L1) I. toxophore; $(\mathbf{M}, \mathbf{T}, \mathbf{C c})$ I. davidii; $(\mathbf{O}, \mathbf{Y})$ I. longshanensis.

Based on many years of field observations, in addition to literature consultation, the following identification key is proposed, and hence the description herein.

\subsection{Analytical Key to the Taxa of Longifilamenta Group of Impatiens in China}

- $\quad$ 1a Basal lobes of lateral united petals with a filamentous long hair, distal lobes of lateral united petals apex retuse with aseta $\ldots \ldots \ldots \ldots \ldots \ldots \ldots \ldots$

- $\quad 1 \mathrm{~b}$ Basal lobes of lateral united petals with a filamentous long hair, distal lobes of lateral united petals apex entire with a filamentous long hair or a seta ........ 3

- $\quad 2$ a Flowers pale rose pink; lateral sepals abaxial midvein narrowly thickened; distal lobes of lateral united petals oblong or suboblong . . . . . . . . . . I. oblongipetala

- $\quad 2 b$ Flowers yellow; lateral sepals abaxial midvein narrowly carinate; distal lobes of lateral united petals dolabriform . . . . . . . . . . . . . . . . . . I. soulieana

- $\quad 3 a$ Lower sepal funnelform or navicular $\ldots \ldots \ldots \ldots \ldots \ldots \ldots \ldots \ldots \ldots \ldots \ldots$

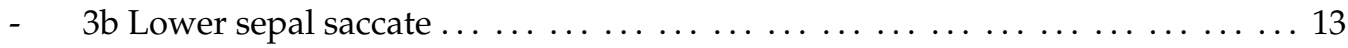


4a Lower sepal navicular, spur absent ................. shennongensis 4 b Lower sepal funnelform, spur 2 -lobed $\ldots \ldots \ldots \ldots \ldots \ldots \ldots \ldots \ldots$ 5a Lateral sepals margin 4-or 5 -denticulate on one side . . . . . . . . I. weihsiensis $5 b$ Lateral sepals margin entire . . . . . . . . . . . . . . . . . . 6 6 Lateral united petals clawed $\ldots \ldots \ldots \ldots \ldots \ldots \ldots \ldots \ldots \ldots \ldots$ $6 \mathrm{~b}$ Lateral united petals not clawed $\ldots \ldots \ldots \ldots \ldots \ldots \ldots \ldots$ 7a Lateral sepals broadly ovate-cordate, abaxial midvein cristate . . . . . . I. toxophora 7b Lateral sepals ovate-orbicular, abaxial midvein without cristate ... . . . I. tayemonii 8a Lateral sepals abaxial midvein carinate narrowly cristate or with a spinelike appendage $\ldots \ldots \ldots \ldots \ldots \ldots \ldots \ldots \ldots \ldots \ldots \ldots$

8 b Lateral sepals abaxial midvein without carinate $\ldots \ldots \ldots \ldots \ldots \ldots \ldots$

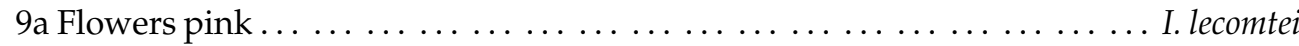

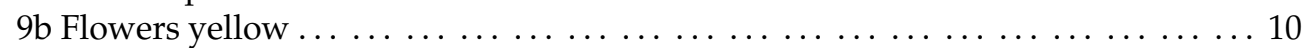

10a lateral sepals ovate, abaxial midvein a spinelike appendage; dorsal petal reniform $\ldots \ldots \ldots \ldots \ldots \ldots \ldots \ldots \ldots \ldots \ldots \ldots \ldots \ldots \ldots \ldots \ldots \ldots \ldots$. cornutisepala 10b lateral sepals orbicular, abaxial midvein carinate or narrowly cristate; dorsal petal

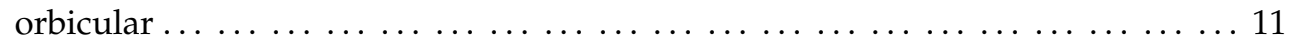
11a Bracts subulate; Lateral sepals $10-20 \mathrm{~mm}$ in diam, abaxial midvein acutely carinate

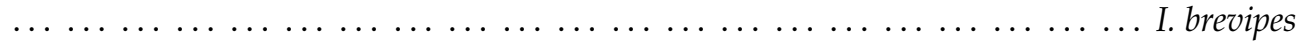
$11 \mathrm{~b}$ Bracts ovate; Lateral sepals ca. $8 \mathrm{~mm}$ in diam, abaxial midvein narrowly cristate $\ldots \ldots \ldots \ldots \ldots \ldots \ldots \ldots \ldots \ldots \ldots \ldots \ldots \ldots \ldots \ldots \ldots \ldots \ldots \ldots$. mussotii 12a Flowers yellow; lateral sepals suborbicular, 1-veined . . . . . . . I. lihengiana $12 \mathrm{~b}$ Flowers pale purple or purple-red; Lateral sepals ovate-orbicular,7-veined ... $\ldots \ldots \ldots \ldots \ldots \ldots \ldots \ldots \ldots \ldots \ldots \ldots \ldots \ldots \ldots \ldots \ldots \ldots \ldots \ldots$ gongchengensis 13a Lateral sepals margin dentate $\ldots \ldots \ldots \ldots \ldots \ldots \ldots \ldots \ldots \ldots \ldots \ldots$

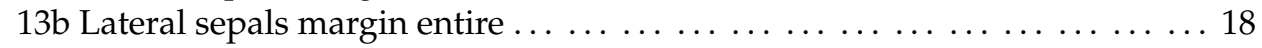
14a Lateral sepals inequilateral, coarsely dentate on one side . . . . . . . I. dicentra $14 \mathrm{~b}$ Lateral sepals equilateral, dentate on both side . . . . . . . . . . . . 15 15a Lateral sepals margin irregularly fimbriate-lacerate $\ldots \ldots \ldots \ldots \ldots \ldots \ldots$ 15 b Lateral sepals margin coarsely dentate $\ldots \ldots \ldots \ldots \ldots \ldots \ldots \ldots$ 16a Flowers yellow, to $4.5 \mathrm{~cm}$ deep; lateral sepals margin and abaxial midvein irregularly fimbriate-lacerate; dorsal petal orbicular . . . . . . . . . . . . I. lacinulifera 16b Flowers pale purple, $2-3 \mathrm{~cm}$ deep; lateral sepals margin irregularly lacerate; dorsal petal broadly reniform $\ldots \ldots \ldots \ldots \ldots \ldots \ldots \ldots \ldots \ldots$. platyceras 17a Lateral united petals clawed; lower sepal with a hooked spur; dorsal petal suborbicular $\ldots \ldots \ldots \ldots \ldots \ldots \ldots \ldots \ldots \ldots \ldots \ldots \ldots \ldots \ldots$ fissicornis 17b Lateral united petals not clawed; lower sepal with a incurved spur; dorsal petal reniform $\ldots \ldots \ldots \ldots \ldots \ldots \ldots \ldots \ldots \ldots \ldots \ldots \ldots \ldots \ldots \ldots \ldots \ldots$ longshanensis 18a Lateral united petals clawed $\ldots \ldots \ldots \ldots \ldots \ldots \ldots$

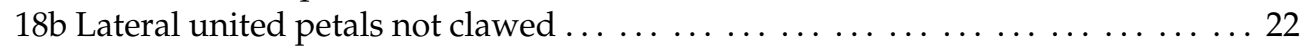

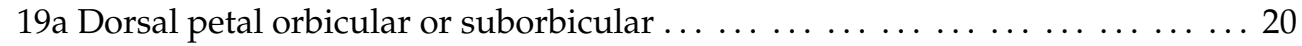

19b Dorsal petal broadly ovate . . . . . . . . . . . . . . . . . . 21

20a Lateral sepals yellow, broadly ovate, 9-veined . . . . . . . . . . . . I. davidii $20 \mathrm{~b}$ Lateral sepals pale green, orbicular, abaxial midvein with a small sac at base ... $\ldots \ldots \ldots \ldots \ldots \ldots \ldots \ldots \ldots \ldots \ldots \ldots \ldots \ldots \ldots \ldots \ldots \ldots \ldots \ldots \ldots$ 21a Lateral sepals abaxially plicated; basal lobes of lateral united petals oblong ...... $\ldots \ldots \ldots \ldots \ldots \ldots \ldots \ldots \ldots \ldots \ldots \ldots \ldots \ldots \ldots \ldots \ldots \ldots \ldots$. plicatisepala 21b Lateral sepals lateral veins reticulate and sunk on abaxial surface with bullate projections among veins; basal lobes of lateral united petals ovate to elliptic ........ $\ldots \ldots \ldots \ldots \ldots \ldots \ldots \ldots \ldots \ldots \ldots \ldots \ldots \ldots \ldots \ldots \ldots \ldots$. bullatisepala 22a Lateral sepals abaxial midvein not thickened, many veined ... . . . I. platychlaena 22b Lateral sepals abaxial midvein fine or slightly thickened, carinate . . . . . 23 23a Lateral sepals apex aristate-acuminate . . . . . . . . . . . I. waldheimiana $23 \mathrm{~b}$ Lateral sepals apex without aristate-acuminate $\ldots \ldots \ldots \ldots \ldots \ldots \ldots$ 
- $\quad$ 24a Flowers ca. $4 \mathrm{~cm}$ deep; lateral sepals abaxial midvein fine, turgid; basal lobes of lateral united petals oblate $\ldots \ldots \ldots \ldots \ldots \ldots \ldots \ldots \ldots \ldots$ I. robusta

- $\quad 24 \mathrm{~b}$ Flowers $2.5-3 \mathrm{~cm}$ deep; lateral sepals abaxial midvein slightly thickened, carinate; basal lobes of lateral united petals ovate-lanceolate ................ I. conaensis

\section{Discussion}

Based on morphological evidence and molecular phylogenetic study, the two new species should be placed in Impatiens sect. Impatiens. I. longshanensis is similar to I. dicentra in its single-flowered inflorescence, yellow flowers, and saccate lower sepal. However, I. longshanensis can easily be distinguished from similar species by its green equilateral lateral sepals, reniform dorsal petal, oblong basal lobe, and dolabriform distal lobes. A more detailed morphological comparison between I. longshanensis and I. dicentra is provided in Table 1. I. lihengiana is superficially similar to I. davidii in having singleflowered inflorescence, dolabriform distal lobes, and 4-colpate pollen grains, but differs by its yellow-green lateral sepals, purple spotted, 1-veined, funnelform lower sepal, not clawed lateral united petals, and ovate-lanceolate basal lobe. A detailed comparison of similar species is given in Table 2.

Table 1. Comparative morphology of Impatiens longshanensis and I. dicentra.

\begin{tabular}{ccc}
\hline Characters & Impatiens longshanensis & Impatiens dicentra \\
\hline Plant height $(\mathrm{cm})$ & $40-80$ & $60-90$ \\
Length of petiole $(\mathrm{cm})$ & $1-3$ & $2-5$ \\
Lateral sepal shape & broadly ovate-orbicular, equilateral & broadly ovate-orbicular, inequilateral \\
Lateral sepal margin & coarsely dentate on both sides & coarsely dentate on one side, rarely entire \\
Lateral sepal dorsum & abaxial midvein inconspicuously thickened & yeldvein narrowly carinate \\
Lateral sepal color & green & $3-5$ \\
Deep of lower sepal $(\mathrm{cm})$ & $1.85-2.3$ & vix 1 \\
Length of spur $(\mathrm{cm})$ & ca.1 & orbicular \\
Dorsal petal & reniform & 2 \\
Bength of lateral united petals $(\mathrm{cm})$ & $2.2-2.9$ & lanceolate \\
Dasal lobes & oblong & lanceolate
\end{tabular}

Table 2. Comparative morphology of Impatiens lihengiana, I. davidii, and I. platychlaena.

\begin{tabular}{|c|c|c|c|}
\hline Characters & Impatiens lihengiana & Impatiens davidii & Impatiens platychlaena \\
\hline Plant height $(\mathrm{cm})$ & $60-70$ & ca. 90 & $60-100$ \\
\hline Leaf shape & $\begin{array}{l}\text { narrowly elliptic or narrowly } \\
\text { ovate-elliptic }\end{array}$ & $\begin{array}{l}\text { ovate-oblong, or } \\
\text { ovate-lanceolate }\end{array}$ & $\begin{array}{l}\text { ovate-oblong, ovate, or } \\
\text { ovate-lanceolate }\end{array}$ \\
\hline Length of petiole $(\mathrm{cm})$ & $1.5-2.5$ & $4-8$ & $2-5$ \\
\hline Flower color & yellow & yellowish & bicolored: purple and yellow \\
\hline Lateral sepal shape & suborbicular, purple spotted & broadly ovate & $\begin{array}{c}\text { broadly orbicular, purple } \\
\text { spotted }\end{array}$ \\
\hline Lateral sepal dorsum & 1-veined & 9-veined & many veined \\
\hline Lateral sepal color & $\begin{array}{l}\text { yellow-green } \\
\text { funnelform, base gradually }\end{array}$ & $\begin{array}{c}\text { yellow } \\
\text { saccate, abruptly narrowed }\end{array}$ & $\begin{array}{l}\text { brown to purple-red when dry } \\
\text { deeply saccate, abruptly }\end{array}$ \\
\hline Lower sepal & $\begin{array}{l}\text { narrowed into an incurved spur, } \\
10-12 \mathrm{~mm} \text { long }\end{array}$ & $\begin{array}{c}\text { into a hooked spur, ca. } 8 \mathrm{~mm} \\
\text { long }\end{array}$ & $\begin{array}{l}\text { narrowed into an incurved } \\
\text { spur, ca. } 6 \mathrm{~mm} \text { long }\end{array}$ \\
\hline Dorsal petal apex & long rostellate & emarginate, shortly rostellate & retuse \\
\hline Lateral united petals & not clawed, $2.5-2.8 \mathrm{~cm}$ & clawed, $1.5-2 \mathrm{~cm}$ & not clawed, $2.5-3 \mathrm{~cm}$ \\
\hline Basal lobes & $\begin{array}{l}\text { ovate-lanceolate, apex with a } \\
\text { filamentous long hair }\end{array}$ & $\begin{array}{l}\text { oblong, apex acuminate or } \\
\text { caudate }\end{array}$ & $\begin{array}{l}\text { orbicular, apex with a } \\
\text { filamentous long hair }\end{array}$ \\
\hline Distal lobes & $\begin{array}{l}\text { dolabriform, apex obtuse, } \\
\text { constricted into a filamentous hair }\end{array}$ & dolabriform, apex obtuse & $\begin{array}{l}\text { dolabriform, longer, with a } \\
\text { long filamentous hair }\end{array}$ \\
\hline Capsule & linear & linear-cylindric & linear \\
\hline
\end{tabular}


Overall, the evidence from the combinations of morphology and phylogeny shows that the longifilamenta group is a cohesive group. For this group, an apex with a filamentous appendage in basal lobes of lateral united petals is the most noticeable feature distinguishing it from other species of Impatiens. In addition, this group is endemic to China, and mainly distributed in western Sichuan, Hubei, southern Henan, Guizhou, northwest Guangxi, and Jiangxi, Taiwan, and it favors montane elevations (1000-3000 m).

Based on the material examined in the present study, the morphological characters of this particular group show a significant variability. The morphology of the lower sepal and lateral sepals shows the diversity of flower structures. The shape of the lower sepal is variable, ranging from navicular, infundibular to saccate (Figure $8 \mathrm{P}-\mathrm{V}$ ). The margin of the lateral sepals is dentate or entire. The abaxial midvein of the lateral sepals ranges from slightly thickened, carinate to a spinelike appendage (Figure $8 \mathrm{~W}-\mathrm{Z}, \mathrm{Aa}-\mathrm{Gg}$ ). Furthermore, the color of flowers of some populations displays a significant variability and instability within intraspecies in these Impatiens taxa. For example, in the previous literature [7], lateral sepals of Impatiens platychlaena are purple, but in this study, the color changes gradually, ranging from purple, yellow with purple spots to pure yellow, based on years of field observation (Figure 8Dd-Gg). Similarly, the flower of Impatiens toxophora is multicolor with the flower color varying from white, yellow to purple within the same population (Figure $8 \mathrm{Hh}-\mathrm{Ll}$ ). These variabilities may blur the lines between species to some extent, hence posing serious challenges to species identification and classification. Therefore, their taxonomic status needs future investigation and more phylogenetic evidence to enhance the understanding of the species relationships within this particular group.

\section{Materials and Methods}

\subsection{Gross Traits}

Specimens of the two new species were collected from Longshan County and quality color photographs were taken in the field. The morphological characteristics of the two species reported in this paper are mostly based on measurements and observations of living plants, specimens, and color photographs.

\subsection{SEM Observations}

Mature whole pollen grains and seeds were collected from flowers and fruits, respectively, in the natural habitats of the plants, and later observed directly under an anatomical macroscope (Olympus SZX10). Dried pollen grains and seeds were carefully mounted on circular metal stubs using double-sided adhesive tape, sputter coated with gold using the JEC-3200 Auto Fine Coater, and then examined and photographed using the JSMIT500 SEM. Pollen characters were described according to the literature [23,24], and seed characters were described according to the literature [25-27].

\subsection{DNA Sequencing and Phylogenetic Analyses}

Genomic DNA of the two new species was extracted from silica gel-dried leaves (Yi-Yan Cong 35443, Yan Xiao LS-794 at HNNU, CSH) using Mag-MK Plant Genomic DNA extraction kits (Sangon Biotech, Shanghai, China). PCR product sequencing was carried out using TSINGKE Biological Technology. Thirty-three representative species from Impatiens were chosen to construct a phylogenetic tree with Hydrocera trifloral as outgroups. DNA sequences of these 34 species were downloaded from GenBank, with the exception of the two new species, I. dicentra, I. platychlaena, and I. longialata. Species names and GenBank accession numbers are provided in Supplementary Materials Table S1.

For phylogenetic analysis, two molecular markers were used: ITS and $a t p B-r b c L[28,29]$. Phylogenetic analysis was conducted using PhyloSuite ver. 1.1.16 [30]. Sequences were assembled and edited in the Mega ver. 7.0.26 [31]. Sequence alignments were carried out using MAFFT ver. 7.222 [32]. The best-fit DNA substitution models were selected by ModelFinder [33]. The Bayesian inference phylogeny was reconstructed using MrBayes 3.2.6 [34] under the GTR + I + G + F model (2 parallel runs, 10 million generations, and 
sampled every 1000 generations), in which the initial $25 \%$ of sampled data was discarded as burn-in. Maximum likelihood phylogenies were inferred using IQ-TREE [35] under the GTR + R3 + F model for 1000 ultrafast [36] bootstraps, in addition to the ShimodairaHasegawa-like approximate likelihood-ratio test [37].

Supplementary Materials: The following are available online at https:/ /www.mdpi.com/article/10 .3390/plants10081697/s1, Figure S1: Image of Impatiens longshanensis holotype specimen, Figure S2: Image of Impatiens lihengiana holotype specimen, Table S1: GenBank accession numbers for species in the phylogenetic analysis.

Author Contributions: Conceptualization, Y.-Y.C. and G.-W.H.; methodology, S.P.; software, S.P. and. Y.-X.S.; formal analysis, Y.X.; investigation, Y.X.; writing—original draft preparation, Y.-X.S.; writing - review and editing, Y.-Y.C. and G.-W.H. All authors have read and agreed to the published version of the manuscript.

Funding: This research was funded by the National Science \& Technology Fundamental Resources Investigation Program of China (2019FY101800). Hunan Province Key Laboratory of Crop Sterile Germplasm Resource Innovation and Application.

Institutional Review Board Statement: Not applicable.

Informed Consent Statement: Not applicable.

Data Availability Statement: Not applicable.

Acknowledgments: The authors are grateful to Fredrick Munyao Mutie for revising the English version of this article and making valuable comments on the manuscript. We are grateful to Jing Tian (HIB) for the beautiful drawing.

Conflicts of Interest: The authors declare no conflict of interest.

\section{References}

1. Blume, C. Balsaminaceae. In Prodromus Florae Peninsulae Indiae Orientalis; Parburry Allen \& Co.: London, UK, 1834; Volume 1, p. 140.

2. Linnaeus, C. Species Plantarum; Salvius: Stockholm, Sweden, 1753; Volume 2, p. 937.

3. Grey-Wilson, C. Impatiens of Africa; Balkema: Rotterdam, The Netherlands, 1980.

4. Mabberley, D.J. Mabberley's Plant-Book, a Portable Dictionary of Plants, Their Classification and Uses, 4th ed.; Cambridge University Press: Cambridge, MA, USA, 2017; p. 1102.

5. Chen, Y.L.; Akiyama, S.; Ohba, H. Balsaminaceae. In Flora of China; Wu, Z.-Y., Raven, P.H., Hong, D.Y., Eds.; Science Press: Beijing, China; Beijing \& Missouri Botanical Garden Press: St. Louis, MO, USA, 2007; Volume 12, pp. 43-113.

6. Yu, S.X.; Janssens, S.B.; Zhu, X.Y.; Lidén, M.; Gao, T.G.; Wang, W. Phylogeny of Impatiens (Balsaminaceae): Integrating molecular and morphological evidence into a new classification. Cladistics 2016, 32, 179-197. [CrossRef]

7. Duric, M.J.; Subotic, A.R.; Prokic, L.T.; Trifunovic-Momcilov, M.M.; Cingel, A.D.; Dragicevic, M.B.; Simonovic, A.D.; Milosevic, S.M. Molecular characterization and expression of four aquaporin genes in Impatiens walleriana during drought stress and recovery. Plants 2021, 10, 154. [CrossRef]

8. Cong, Y.Y.; Cai, X.Z.; Liu, K.M. Impatiens unguiculata (Balsaminaceae), a new species from Xizang, China. Ann. Bot. Fenn. 2013, 50, 165-168. [CrossRef]

9. $\quad$ Kuang, R.P.; Duan, L.D.; Gu, J.Z.; Cai, X.Z.; Cong, Y.Y.; Liu, K.M. Impatiens liboensis sp. nov. (Balsaminaceae) from Guizhou, China. Nord. J. Bot. 2014, 32, 463-467. [CrossRef]

10. Luo, Q.; Wang, T.J.; Zhao, L.H. Impatiens menghuochengensis sp. nov. (Balsaminaceae) from Sichuan, China. Nord. J. Bot. 2014, 6, 839-843. [CrossRef]

11. Cai, X.Z.; Hu, G.W.; Cong, Y.Y. Impatiens xanthinoides (Balsaminaceae), a new species from Yunnan, China. Phytotaxa 2015, 227, 261-267. [CrossRef]

12. Tan, Y.H.; Liu, Y.N.; Jiang, H.; Zhu, X.X.; Zhang, W.; Yu, S.X. Impatiens pandurata (Balsaminaceae), a new species from Yunnan, China. Bot. Stud. 2015, 56, e29. [CrossRef] [PubMed]

13. Lu, Z.C.; Pan, B.; Huang, F.Z.; Liu, Y. Impatiens gongchengensis (Balsaminaceae), a new species from Guangxi, Southern China. Taiwania 2020, 65, 1-4. [CrossRef]

14. Peng, S.; Cong, Y.Y.; Tian, J.; Zhang, C.F.; Hu, G.W.; Wang, Q.F. Impatiens bullatisepala (Balsaminaceae), a new species from Guizhou, China. Phytotaxa 2021, 500, 217-224. [CrossRef]

15. Song, Y.X.; Peng, S.; Cong, Y.Y.; Zheng, Y.M. Impatiens rapiformis, a new species of Impatiens with root tuber from Yunnan, China. Nord. J. Bot. 2021, 39. [CrossRef]

16. Chen, Y.L. Balsaminaceae. In Flora Reipublicae Popularis Sinica; Science Press: Beijing, China, 2001; Volume 47, pp. 1-243. 
17. Yu, S.X. Balsaminaceae of China; Peking University Press: Beijing, China, 2012.

18. Hooker, J.D. Les especes du genre “Impatiens" dans l'herbier du Museum de Paris. Nov. Arch. Mus. Nat. Hist. Paris. Ser. 1908, 10, 233-272.

19. Zou, C.Y.; Liu, Y.; Li, J.; Yu, S.X. Impatiens plicatisepala (Balsaminaceae), a new species from Guangxi, China. Taiwania 2020, 65, 451-455. [CrossRef]

20. Yu, S.X.; Zhou, X.R.; Chen, Y.L. Impatiens cornutisepala (Balsaminaceae), a New Species from Guangxi, China. Novon 2009, 19, 562-566. [CrossRef]

21. Cong, Y.Y.; Liu, K.M. Impatiens oblongipetala (Balsaminaceae), a New Species from Yunnan, China. Novon 2010, $20,392-395$. [CrossRef]

22. Wang, Q.; Gadagkar, S.R.; Deng, H.P.; Yang, Z.M.; Yu, F.Q. Impatiens shennongensis (Balsaminaceae): A new species from Hubei, China. Phytotaxa 2016, 244, 96-100. [CrossRef]

23. Wang, K.F.; Wang, X.Z. Outline of Palynology; Beijing Universit Press: Beijing, China, 1983.

24. Lu, Y.Q. Pollen morphology of Impatiens L. (Balsaminaceae) and its taxonomic implications. Acta Phytotax. Sin. 1991, $29,352-357$.

25. Lu, Y.Q.; Chen, Y.L. Seed morphology of Impatiens L. (Balsaminaceae) and its taxonomic significance. Acta Phytotax. Sin. 1991, 29, 252-257.

26. Liu, C.J.; Lin, Q.; He, J.X. Methods and terminology of study on seed morphology from China. Acta Bot. Boreali Occident. Sin. 2004, 24, 178-188.

27. Song, Y.; Yuan, Y.M.; Küpfer, P. Seedcoat micromorphology of Impatiens (Balsaminaceae) from China. Bot. J. Linn. Soc. 2005, 149, 195-208. [CrossRef]

28. Yuan, Y.M.; Song, Y.; Geuten, K.; Rahelivololona, E.; Wohlhauser, S.; Fischer, E.; Küpfer, P. Phylogeny and biogeography of Balsaminaceae inferred from ITS sequence data. Taxon 2004, 53, 391-404. [CrossRef]

29. Janssens, S.; Geuten, K.; Yuan, Y.M.; Song, Y.; Küpfer, P.; Smets, E. Phylogenetics of Impatiens and Hydrocera (Balsaminaceae) using chloroplast atpB-rbcL spacer sequences. Syst. Bot. 2006, 31, 171-180. [CrossRef]

30. Zhang, D.; Gao, F.; Jakovlić, I.; Zou, H.; Zhang, J.; Li, W.X.; Wang, G.T. PhyloSuite: An integrated and scalable desktop platform for streamlined molecular sequence data management and evolutionary phylogenetics studies. Mol. Ecol. Resour. 2020, 20, 348-355. [CrossRef] [PubMed]

31. Kumar, S.; Stecher, G.; Li, M.; Knyaz, C.; Tamura, K. MEGA X: Molecular evolutionary genetics analysis across computing platforms. Mol. Biol. Evol. 2018, 35, 1547-1549. [CrossRef] [PubMed]

32. Katoh, K.; Standley, D.M. MAFFT multiple sequence alignment software ver. 7: Improvements in performance and usability. Mol. Biol. Evol. 2013, 30, 772-780. [CrossRef] [PubMed]

33. Kalyaanamoorthy, S.; Minh, B.Q.; Wong, T.K.; VonHaeseler, A.; Jermiin, L.S. ModelFinder: Fast model selection for accurate phylogenetic estimates. Nat. Methods 2017, 14, 587-589. [CrossRef] [PubMed]

34. Ronquist, F.; Teslenko, M.; VanDerMark, P.; Ayres, D.L.; Darling, A.; Höhna, S.; Huelsenbeck, J.P. MrBayes 3.2: Efficient Bayesian phylogenetic inference and model choice across a large model space. Syst. Bot. 2012, 61, 539-542. [CrossRef] [PubMed]

35. Nguyen, L.T.; Schmidt, H.A.; VonHaeseler, A.; Minh, B.Q. IQ-TREE: A fast and effective stochastic algorithm for estimating maximum-likelihood phylogenies. Mol. Biol. Evol. 2015, 32, 268-274. [CrossRef]

36. Minh, B.Q.; Nguyen, M.A.T.; von Haeseler, A. Ultrafast approximation for phylogenetic bootstrap. Mol. Biol. Evol. 2013, 30, 1188-1195. [CrossRef] [PubMed]

37. Guindon, S.; Dufayard, J.F.; Lefort, V.; Anisimova, M.; Hordijk, W.; Gascuel, O. New algorithms and methods to estimate maximum-likelihood phylogenies: Assessing the performance of PhyML 3.0. Syst. Bot. 2010, 59, 307-321. [CrossRef] 